\title{
Diagnostic Challenges in Newborns and Infants with Coagulation Disorders
}

\author{
Wolfgang Eberl ${ }^{1}$ \\ ${ }^{1}$ Department of Pediatrics, Städtisches Klinikum Braunschweig, \\ Braunschweig, Germany \\ Hämostaseologie 2020;40:84-87.
}

\begin{abstract}
Keywords

- coagulation diagnostics

- infant

- preterm

- newborn

\section{Zusammenfassung}

Schlüsselwörter

- gerinnungsdiagnostik

- säugling

- frühgeburt

- neugeborene

Laboratory diagnostics in children and adolescents, especially in newborns and very small children, differ considerably compared with laboratory diagnostics in adults. This applies to all individual steps of the examination (i.e., the indication, the preanalytical phase, the analysis itself, and interpretation of the findings). This is particularly true in the diagnostics of hemostasis, in which small sample volumes and relatively error prone coagulation tests are posing particular challenges to the strategy, performance, and evaluation of the tests. Differences in the individual steps are illustrated below.

Labordiagnostik im Kindes - und Jugendalter, vor allem bei Neugeborenen und Säuglingen unterscheidet sich erheblich von Untersuchungen bei Erwachsenen. Dies betrifft alle Schritte der Untersuchung (Indikation, präanalytische Phase, Analyse und Befundinterpretation). Bei der Gerinnungsdiagnostik ist dies besonders deutlich, da die geringe zur Verfügung stehende Probenmenge und die Störempfindlichkeit der Testsysteme hier besondere Herausforderungen an die Planung, Durchführung und Bewertung der Tests stellen. Die Besonderheiten und Unterschiede sollen hier dargestellt werden.
\end{abstract}

\section{Introduction}

The clinical problems that today lead to presentation of patients in an outpatient coagulation clinic vary greatly from age group to age group. In recent years, the main focus in adults has been on clarifying their tendency toward thrombosis, monitoring anticoagulation, and clarifying their tendency toward bleeding. In childhood and adolescence, perioperative coagulation diagnostics and the assessment of an increased bleeding tendency are the most common indication. In recent years, there is also increasing demand in the field of neonatology and intensive care diagnostics especially for catheter-related complications or sepsis-related coagulation disorders. Standard routine parameters are not suitable. ${ }^{1}$ A premature infant weighing of $1,000 \mathrm{~g}$ has an intravascular volume of $100 \mathrm{~mL}$; a newborn infant, approximately $250 \mathrm{~mL}$. This means that the sampling of a standard $5-\mathrm{mL}$ vial represents 2 or $5 \%$ of the total blood volume. The first challenge is therefore to limit diagnostics to the bare essentials. Routine screening diagnostics or the creation of

received

August 19, 2019

accepted after revision

November 27, 2019

"profiles" are therefore obsolete. For instance, in the case of a familial predisposition, there is no indication for a thrombophilia diagnosis in prepubescent children who are not clinically affected by vascular occlusion with the exception of determination of antithrombin III or protein C in families with severe defects. The routine preoperative coagulation diagnostics in infants can almost always be replaced by taking a systematically collected medical history. ${ }^{2}$ The most important criterion for selecting the particular parameters to be investigated is therefore whether the result has a therapeutic consequence. The ideal diagnostic procedure should be based on the leading symptom with a clear target orientation. - Tables 1 to 3 provide suggestions for frequently asked questions.

\section{Preanalytical Problems}

An abundance of possible disruptive factors and sources of error in coagulation diagnostics has long been identified and led to the well-known recommendations for sample @ 2020 Georg Thieme Verlag KG
Stuttgart · New York
DOI https://doi.org/

10.1055/s-0040-1701475. ISSN 0720-9355. 
Table 1 Stepwise diagnostic work-up of acute bleeding event

\begin{tabular}{|l|l|}
\hline Preterm/newborn & Acute bleeding event \\
\hline Hereditary coagulopathy & Acquired coagulopathy \\
\hline von Willebrand disease & Thrombocytopenia \\
\hline Hemophilia A/B & Vitamin K deficiency \\
\hline Other factor deficiencies & DIC \\
\hline Thrombocytopenia & \\
\hline Platelet function defects & $\begin{array}{l}\text { Blood count, PT, aPTT, } \\
\text { fibrinogen, F XII, vWF:Ag }\end{array}$ \\
\hline Level 1 & $\begin{array}{l}\text { Single factors depending } \\
\text { on PT/aPTT constellation }\end{array}$ \\
\hline Level 2 & $\begin{array}{l}\text { Platelet function analysis } \\
\text { (aggregometry) }\end{array}$ \\
\hline Level 3 & \\
\hline Therapeutic implications & Vitamin K substitution, platelet transfusion, FFP, or single \\
factor infusion
\end{tabular}

Abbreviations: aPTT, activated thromboplastin time; DIC, disseminated intravascular coagulation; FFP, fresh frozen plasma; PT, prothrombin time.

collection. ${ }^{3-5}$ Technical aspects have a completely different significance in the training of a pediatrician than in other medical staff; it often takes months to years until venipuncture for blood collection is safely mastered, especially in premature and new-born babies. This means that hemolytic samples, underfilled tubes or clotted samples, and even clot formation are rather frequent during blood collection in the coagulation laboratory of a pediatric clinic. The initial quality control by the technical staff and taking notes of the diag-

Table 2 Stepwise diagnostic work-up of neonatal thrombosis or stroke

\begin{tabular}{|c|c|}
\hline Preterm/newborn & Thrombosis, stroke \\
\hline Hereditary coagulopathy & Acquired coagulopathy \\
\hline Protein C/S deficiency & Polyglobulia \\
\hline Antithrombin III deficiency & Sepsis/DIC \\
\hline Other thrombophilic states & Central line associated \\
\hline \multicolumn{2}{|l|}{$\begin{array}{l}\text { TTP when additional } \\
\text { hemolysis }\end{array}$} \\
\hline Level 1 & $\begin{array}{l}\text { Blood count, PT, aPTT, } \\
\text { D-dimer, antithrombin III, } \\
\text { protein C }\end{array}$ \\
\hline \multirow[t]{2}{*}{ Level 2} & $\begin{array}{l}\text { Single factors depending on } \\
\text { PT/aPTT constellation }\end{array}$ \\
\hline & $\begin{array}{l}\text { ADAMTS13 activity when } \\
\text { hemolysis is present }\end{array}$ \\
\hline \multicolumn{2}{|l|}{ Therapeutic implications } \\
\hline $\begin{array}{l}\text { Monitoring of anticoagulat } \\
\text { C/antithrombin III }\end{array}$ & ubstitution of protein \\
\hline
\end{tabular}

Abbreviations: aPTT, activated thromboplastin time; DIC, disseminated intravascular coagulation; PT, prothrombin time; TTP, thrombotic thrombocytopenic purpura.
Table 3 Diagnostic work-up of bleeding symptoms or acute event (infants)

\begin{tabular}{|l|l|}
\hline Infant & Unusual bleeding \\
\hline Hereditary coagulopathy & Acquired coagulopathy \\
\hline von Willebrand disease & Thrombocytopenia \\
\hline Hemophilia A/B & Vitamin K deficiency \\
\hline Other factor deficiencies & \\
\hline Thrombocytopenia & \\
\hline Platelet function defects & $\begin{array}{l}\text { Blood count, PT, aPTT, } \\
\text { fibrinogen, F XII, } \\
\text { vWF:Ag/activity }\end{array}$ \\
\hline Level 1 & $\begin{array}{l}\text { Single factors depending on } \\
\text { PT/aPTT constellation }\end{array}$ \\
\hline Level 2 & $\begin{array}{l}\text { Differential diagnosis of } \\
\text { thrombocytopenia } \\
\text { (blood smear) }\end{array}$ \\
\hline & $\begin{array}{l}\text { Platelet function analysis } \\
\text { (aggregometry/flow cytometry) }\end{array}$ \\
\hline Level 3 & \multicolumn{2}{|l}{ diagnostic consequences } \\
\hline Therapeutic implications and
\end{tabular}

Abbreviations: aPTT, activated thromboplastin time; PT, prothrombin time.

nostic limitations are therefore essential for the later interpretation of the results. In a neonatal intensive care unit, hematocrit values between 30 and $70 \%$ are not uncommon. This can compromise the measured results; since the plasma:citrate ratio varies from 6.3:1 to 2.7:1 with depending on a corresponding "dilution effect." ${ }^{\text {"-8 }}$ However, this also implies that underfilled and overfilled samples can still be examined depending on the hematocrit value. For this purpose, we have developed a tool that allows the technician to assess whether the sample can be measured based on a known hematocrit value ( - Fig. 1 ).

\section{Analytics}

In almost all clinics, coagulation diagnostics are performed in central laboratories in which samples of children are practically quantitatively negligible. The selection of devices, tests, and reagents will therefore rarely take into account the specificity of the pediatric needs. However, there are differences in the systems available on the market, especially with regard to the required sample volume. In principle, no major difference needs to be considered when selecting test systems except in the case of derived fibrinogen, which is not suitable for newborns or infants because of poor and inconsistent correlation between prothrombin time-derived fibrinogen determination and the Clauss method. Icteric and lipemic plasma disturb the PTZ-derived fibrinogen determination. An ideal investigation would be a global test that would provide as much information as possible with as little starting material as possible. Unfortunately, the otherwise 


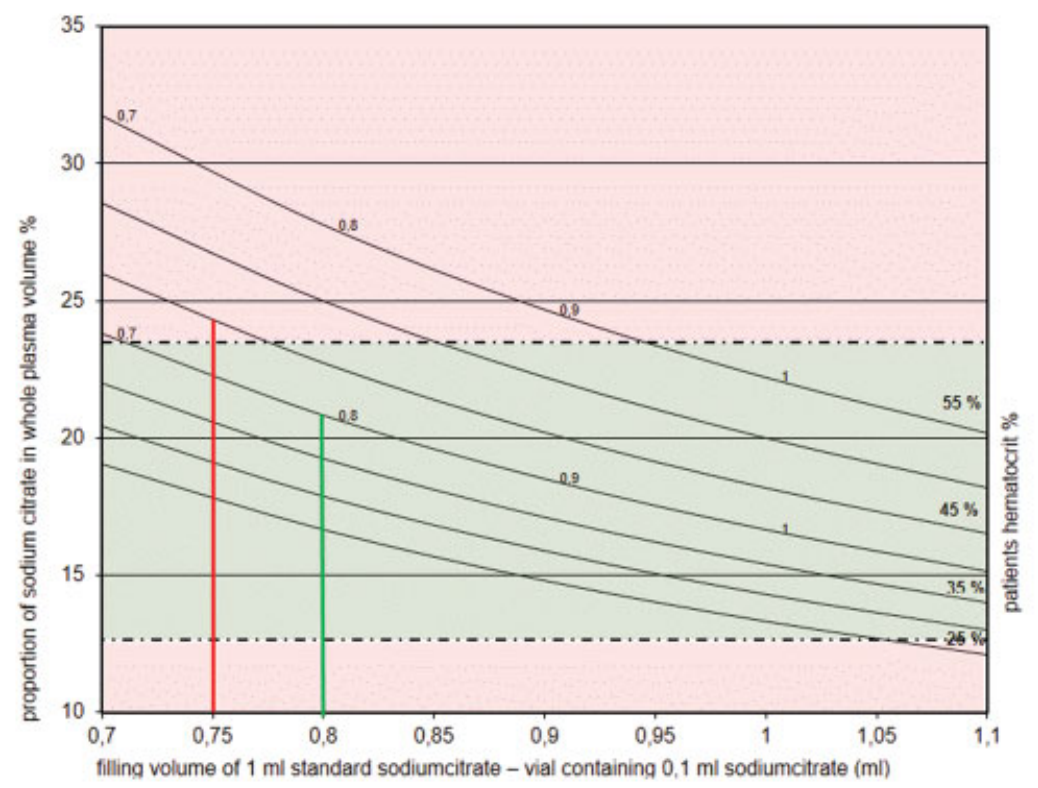

Fig. 1 Nomogram to estimate relative citrate percentage of the sample depending on degree of filling and hematocrit of the sample. The variation of measured results were below 5\% for PT, aPTT, Fibrinogen, F II, F V, F VIII, F IX, Antithrombin and Protein C (own data) between 12,5\% and $23 \%$ citrate percentage. An example of an underfilled sample (red) what cannot be analyzed and another example (green) what is acceptable is given.

useful prothrombin time and activated thromboplastin time in childhood are not suitable for preoperative diagnostics, ${ }^{2}$ for a reliable diagnosis or for the exclusion of a factor deficiency, because false-positive and false-negative test results are frequent. ${ }^{1}$ In addition, the hope that thrombelastography would be able to remedy this problem has not completely fulfilled, ${ }^{9,10}$ but actually some promising studies in neonatal intensive care units were done. ${ }^{9,11,12}$ Similarly, the "in vitro bleeding time" (PFA-100 or similar devices) could not be established as a screening method in childhood and adolescence since relevant preanalytical implications, and as well as poor sensitivity and specificity for individual problems limit the diagnostic statement power in pediatrics. ${ }^{13-15}$ Platelet function diagnostics, which are fortunately only rarely necessary, require relatively large sample quantities using traditional aggregometry methods and can pose considerable problems. By using flow cytometry with relatively small sample quantities, at least some of the more frequent thrombocytopathies (i.e., Glanzmann thrombasthenia, Bernard-Soulier syndrome, or storage pool disease) can be excluded.

\section{Interpretation of Findings}

However, the greatest challenge in diagnostics in this age group is evaluating interpreting the test results obtained. The coagulation system of premature babies, newborns, and infants in the first year of life is subject to a maturation dynamic that requires a differentiated knowledge of agerelated reference values. The first publication of such data by Maureen Andrew ${ }^{16}$ was a milestone. Several current publications on this topic have appeared in recent years. ${ }^{17-20}$ These also take into account the fact that the technical development from early mechanical detection methods to light-optical methods and above all the development of new parameters now require a more differentiated examination interpretation of the findings. ${ }^{21}$ In many publications, it is recommended to establish laboratory reference values ${ }^{22-26}$ that refer to the local conditions of the equipment and the selection of the reagents. However, this requirement quickly would breach ethical limits necessitating the examination of healthy premature and newborns as well as infants. As a rule, it is best to use published reference values that have been created using a similar methodology. However, it is crucial that the connections between the clinical symptoms and, if necessary, the dynamics of the clinical disease course are closely correlated with the laboratory findings. Therefore the clinician and the laboratory manager should maintain a close communication with each other. At this point, it should be mentioned once again that personal and family medical histories can often provide valuable information.

\section{Summary}

In newborns and infants, the diagnosis of coagulation disorders (from the indication to the interpretation of the findings) differs in many ways from that of older children or adults. Ideally, a pediatric hemostaseologist can discuss the selection of equipment and test systems in the central laboratory. The interpretation of the findings in intensive care units and in surgery also requires expertise that takes into account the specific characteristics of each age group. In a large hospital, the proportion of coagulation tests for newborns, premature babies, and infants represents only a negligible proportion part of the total workflow volume of a 
in the laboratory. Therefore, constant contact between the clinician and the laboratory is mandatory to ensure a high level of quality.

\section{Conflict of Interest}

None.

\section{References}

1 Pal S, Curley A, Stanworth SJ. Interpretation of clotting tests in the neonate. Arch Dis Child Fetal Neonatal Ed 2015;100(03): F270-F274

2 Bidlingmaier C, Eberl W, Knöfler R, Olivieri M, Kurnik K. Haemostatic testing prior to elective surgery in children? Not always!. Hamostaseologie 2009;29(01):64-67

3 Lippi G, Salvagno GL, Montagnana M, Lima-Oliveira G, Guidi GC, Favaloro EJ. Quality standards for sample collection in coagulation testing. Semin Thromb Hemost 2012;38(06):565-575

4 Adcock Funk DM, Lippi G, Favaloro EJ. Quality standards for sample processing, transportation, and storage in hemostasis testing. Semin Thromb Hemost 2012;38(06):576-585

5 Lippi G, Franchini M, Montagnana M, Salvagno GL, Poli G, Guidi GC. Quality and reliability of routine coagulation testing: can we trust that sample? Blood Coagul Fibrinolysis 2006;17(07): 513-519

6 Nagler M, Kathriner S, Bachmann LM, Wuillemin WA. Impact of changes in haematocrit level and platelet count on thromboelastometry parameters. Thromb Res 2013;131(03):249-253

7 van den Besselaar AM, Witteveen E, van der Meer FJ. Influence of haematocrit on international normalised ratio (INR) differences between a whole blood point-of-care coagulation monitor and reference prothrombin time in plasma. Thromb Haemost 2008; 100(06):1181-1184

8 Blombäck M, Konkle BA, Manco-Johnson MJ, Bremme K, Hellgren M, Kaaja R; ISTH SSC Subcommittee on Women's Health Issues. Preanalytical conditions that affect coagulation testing, including hormonal status and therapy. J Thromb Haemost 2007;5(04): 855-858

9 Carter BG, Carland E, Monagle P, Horton SB, Butt W. Impact of thrombelastography in paediatric intensive care. Anaesth Intensive Care 2017;45(05):589-599

10 Mirabella L, Cotoia A, Colacicco G, et al. Reference values for coagulation assessment in full-term newborns. Minerva Anestesiol 2017;83(04):369-374

11 Sokou R, Konstantinidi A, Stefanaki C, et al. Thromboelastometry: studying hemostatic profile in small for gestational age neonates-a pilot observational study. Eur J Pediatr 2019;178 (04):551-557
12 Sokou R, Giallouros G, Konstantinidi A, et al. Thromboelastometry for diagnosis of neonatal sepsis-associated coagulopathy: an observational study. Eur J Pediatr 2018;177(03):355-362

13 Hayward CP, Harrison P, Cattaneo M, Ortel TL, Rao AK; Platelet Physiology Subcommittee of the Scientific and Standardization Committee of the International Society on Thrombosis and Haemostasis. Platelet function analyzer (PFA)-100 closure time in the evaluation of platelet disorders and platelet function. J Thromb Haemost 2006;4(02):312-319

14 Podda GM, Bucciarelli P, Lussana F, Lecchi A, Cattaneo M. Usefulness of PFA-100 testing in the diagnostic screening of patients with suspected abnormalities of hemostasis: comparison with the bleeding time. J Thromb Haemost 2007;5(12):2393-2398

15 Roschitz B, Thaller S, Koestenberger M, et al. PFA-100 closure times in preoperative screening in 500 pediatric patients. Thromb Haemost 2007;98(01):243-247

16 Andrew M, Vegh P, Johnston M, Bowker J, Ofosu F, Mitchell L. Maturation of the hemostatic system during childhood. Blood 1992;80(08):1998-2005

17 Male C, Johnston M, Sparling C, Brooker L, Andrew M, Massicotte P. The influence of developmental haemostasis on the laboratory diagnosis and management of haemostatic disorders during infancy and childhood. Clin Lab Med 1999;19(01):39-69

18 Kuhle S, Male C, Mitchell L. Developmental hemostasis: pro- and anticoagulant systems during childhood. Semin Thromb Hemost 2003;29(04):329-338

19 Monagle P, Ignjatovic V, Savoia H. Hemostasis in neonates and children: pitfalls and dilemmas. Blood Rev 2010;24(02):63-68

20 Jaffray J, Young G. Developmental hemostasis: clinical implications from the fetus to the adolescent. Pediatr Clin North Am 2013;60(06):1407-1417

21 Toulon P. Developmental hemostasis: laboratory and clinical implications. Int J Lab Hematol 2016;38(Suppl 1):66-77

22 Attard C, van der Straaten T, Karlaftis V, Monagle P, Ignjatovic V. Developmental hemostasis: age-specific differences in the levels of hemostatic proteins. J Thromb Haemost 2013;11(10):1850-1854

23 Toulon P, Berruyer M, Brionne-François M, et al. Age dependency for coagulation parameters in paediatric populations. Results of a multicentre study aimed at defining the age-specific reference ranges. Thromb Haemost 2016;116(01):9-16

24 Lippi G, Franchini M, Montagnana M, Guidi GC. Coagulation testing in pediatric patients: the young are not just miniature adults. Semin Thromb Hemost 2007;33(08):816-820

25 Appel IM, Grimminck B, Geerts J, Stigter R, Cnossen MH, Beishuizen A. Age dependency of coagulation parameters during childhood and puberty. J Thromb Haemost 2012;10:2254-2263

26 Christensen RD, Baer VL, Lambert DK, Henry E, Ilstrup SJ, Bennett ST. Reference intervals for common coagulation tests of preterm infants (CME). Transfusion 2014;54(03):627-632, quiz 626 